\title{
Zircon SHRIMP U-Pb ages of the Gangdese Batholith and implications for Neotethyan subduction in southern Tibet
}

\author{
Da-Ren Wen ${ }^{a}$, Dunyi Liu ${ }^{b}$, Sun-Lin Chung ${ }^{\mathrm{a}, *}$, Mei-Fei Chu ${ }^{\mathrm{a}}$, Jianqing Ji ${ }^{\mathrm{c}}$, Qi Zhang ${ }^{\mathrm{d}}$, Biao Song ${ }^{\mathrm{b}}$, \\ Tung-Yi Lee ${ }^{\mathrm{e}}$, Meng-Wang Yeh ${ }^{\mathrm{e}}$, Ching-Hua Lo ${ }^{\mathrm{a}}$ \\ a Department of Geosciences, National Taiwan University, Taipei, Taiwan \\ b Institute of Geology, Chinese Academy of Geological Sciences, Beijing, China \\ c School of Earth and Space Sciences, Peking University, Beijing, China \\ d Institute of Geology and Geophysics, Chinese Academy of Sciences, Beijing, China \\ e Department of Earth Sciences, National Taiwan Normal University, Taipei, Taiwan
}

\section{A R T I C L E I N F O}

\section{Article history:}

Received 18 February 2008

Accepted 7 March 2008

Editor: B. Bourdon

\section{Keywords:}

Tibet

Gangdese Batholith

Zircon U-Pb dating

Neotethyan subduction

\begin{abstract}
A B S T R A C T
The Trans-Himalayan magmatism, which occurred extensively in the Lhasa terrane of southern Tibet, has long been related to the Neotethyan subduction before the India-Asia collision. To better delineate the magmatic duration, we report a geochronological study with 25 SHRIMP zircon U-Pb ages from the Gangdese Batholith that represents the largest Trans-Himalayan plutonic complex. The results suggest two distinct stages of plutonism in the Late Cretaceous (ca. 103-80 Ma) and early Paleogene (ca. 65-46 Ma), respectively. Our new data confirm if not refine the notion that a Gangdese magmatic gap or quiescent period existed between ca. 80 and $70 \mathrm{Ma}$. It is furthermore identified that the early stage ended with adakitic intrusion and the latter stage is marked by a peak activity at ca. $50 \mathrm{Ma}$. We attribute the cessation of the early stage, and following magmatic gap, to a flattening of the northward Neotethyan subduction, and the initiation of the latter stage to rollback of the subducted slab. The proposed scenarios can also account for the southward migration and intensification of Cretaceous to Paleogene volcanism in the Lhasa terrane that demonstrates a coeval, eruptive "flare-up" event around $50 \mathrm{Ma}$, interpreted as the result of detaching the Neotethyan oceanic slab from the adherent, more buoyant Indian continental lithosphere owing to the IndiaAsia collision. Our model is, moreover, in general accord with sedimentary and structural geologic records from southern Tibet where subduction-related orogenesis appears to have evolved through time before India started colliding Asia.
\end{abstract}

(C) 2008 Elsevier B.V. All rights reserved.

\section{Introduction}

Although studies of mountain building have been traditionally focused on collisional orogens characterized by closure of ocean basins and subsequent collision of continental blocks, growing attention has been paid to accretionary type of orogenesis whose role in the continental growth throughout Earth history has been recognized based largely on more recent works in the circum-Pacific regions (e.g., Maruyama, 1997; Collins, 2002; Saleeby, 2003; Hyndman et al., 2005). The Tibetan plateau, generally regarded as the archetype of collisional orogens, is also a unique natural laboratory for investigating accretionary orogenic processes in its southern part because it was located in an Andean-style convergent margin related to the northward subduction of the Neotethyan oceanic lithosphere before India collided with Asia along the Yarlu-Zangpo suture (Allegrè et al., 1984; Searle et al., 1987; Hodges, 2000; Yin and Harrison, 2000). Knowledge about

* Corresponding author. Department of Geosciences, National Taiwan University, P. O. Box 13-318, Taipei 10699, Taiwan. Tel.: +886 23366 2934; fax: +8862 23636095 .

E-mail address: sunlin@ntu.edu.tw (S.-L. Chung). pre-collisional geohistory in the region, however, is limited because most of previous studies concentrated on post-collisional geology regardless of the consequence that any models thereby proposed for Tibetan tectonic evolution situated actually on general assumptions of initial conditions with scarce data. We therefore carried out a systematic study of the Cretaceous-early Tertiary Gangdese Batholith from the southern Lhasa terrane for a better understanding of the magmatic and geodynamic processes that had been operating in this part of the convergent margin. This paper reports 25 SHRIMP zircon U$\mathrm{Pb}$ age results, which allow us to evaluate the existing age information and thus identify two principal stages of the intrusive activity with a magmatic gap in between. These results, combined with our petrochemical observations and available geologic data, serve as important new constraints for not only the magmatic but also tectonic evolution in southern Tibet before the India-Asia collision.

\section{The Gangdese Batholith}

The belt of granitoids that crops out immediately north of the Yarlu-Zangpo suture for a distance of $\sim 2500 \mathrm{~km}$ in southern Tibet 


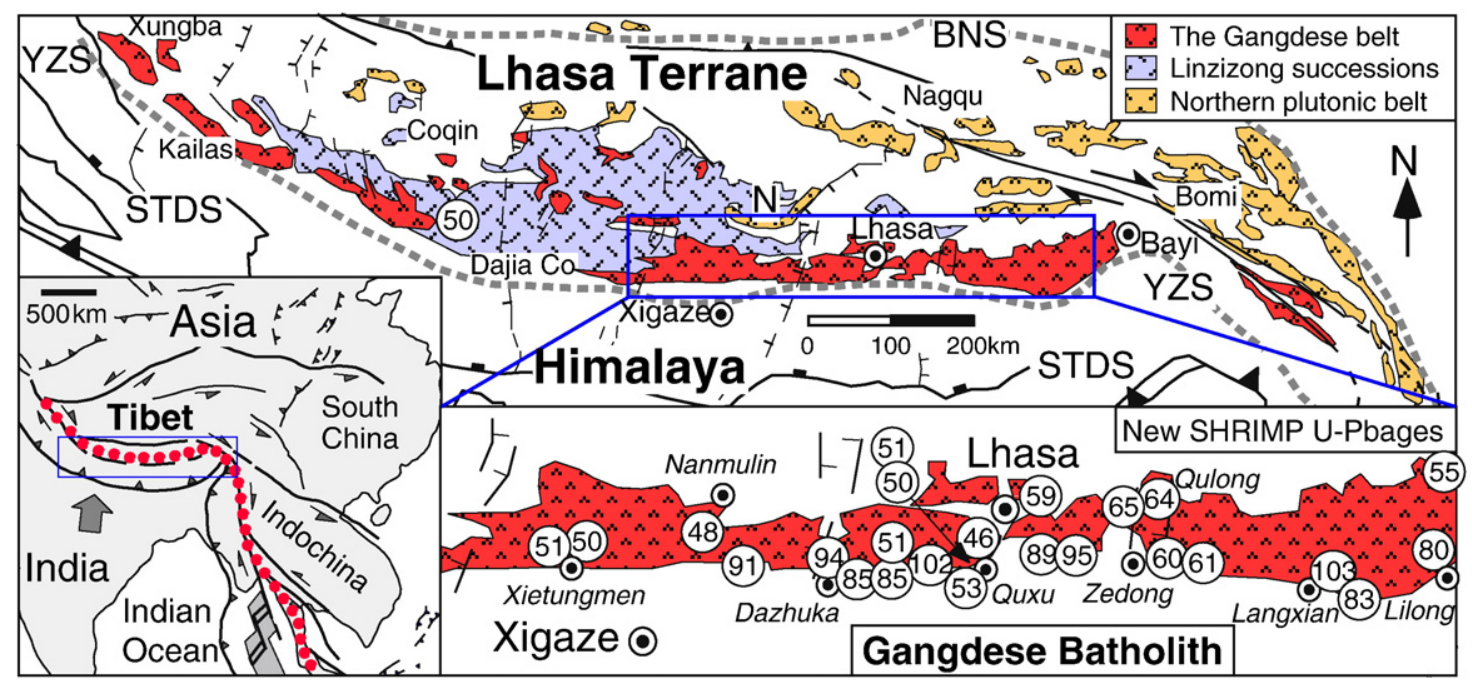

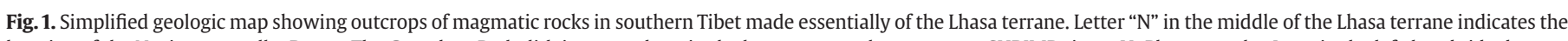

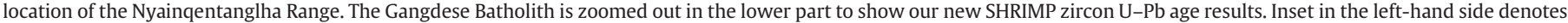

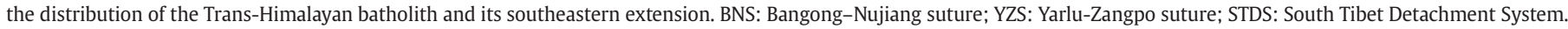

(Fig. 1) has been termed the "Trans-Himalayan batholith" (cf. Searle et al., 1987; for review). East of $80^{\circ} \mathrm{E}$ this batholith belt is represented principally by the voluminous Gangdese Batholith or "Gangdese plutonic complex" (Chang and Zheng, 1973; Allegrè et al., 1984); and the basic geology of its western edge in the Kailas region was first outlined by Heim and Gansser (1939). The widespread granitoids within the Lhasa terrane of southern Tibet may be divided into two belts: (1) the northern plutonic belt that consists essentially of Cretaceous peraluminous or S-type granites as those exposed in the Nyainqentanghla Range (Xu et al., 1985; Harris et al., 1990) and (2) the southern Gangdese belt dominated by Late Cretaceous to Eocene granitoids with I-type geochemical composition (Debon et al., 1986; XBGMR, 1993; Wen et al., 2003; Mo et al., 2005). Emplacement of the latter was associated with extensive volcanism that resulted in the gently folded or flat-lying Linzizong volcanic successions (Fig. 1) over the southern Lhasa terrane (Coulon et al., 1986; XBGMR, 1993; Mo et al., 2005; Lee, 2007; He et al., 2007). Although the petrogenesis of the northern magmatic belt remains debated (see below), the Gangdese and Linzizing rocks have been widely regarded as the products of an Andean-type convergent margin along the southern Asian continent due to northward subduction of the Neotethyan oceanic lithosphere before the India-Asia collision (Allegrè et al., 1984; Searle et al., 1987; Yin and Harrison, 2000; and references therein). Our recent work (Chu et al., 2006), moreover, suggested this subduction to have started since at least Early Jurassic time and thus been longer lasting than previously thought.

The Gangdese Batholith, the largest Trans-Himalayan plutonic complex (Fig. 1), shows a wide range of lithologies from gabbro, diorite, granodiorite to granite. Its most abundant rock type is of intermediate chemical composition and occurs as biotite-hornblende-bearing diorite and/or granodiorite. Geochemically, these rocks are comparable to the Itype granitoids such as those from the Cordilleran regions in the circumPacific (e.g., Chappell and White, 1974; Pitcher, 1982) and have Sr and Nd isotope ratios indicative of significant involvement of a juvenile mantle source in the magma generation (Harris et al., 1988; Jiang et al., 1999; Wen et al., 2003; Mo et al., 2005; Chu et al., 2006; Wen, 2007; Wen et al., 2008). Before our studies, published geochronologic data from different localities within the Batholith document magmatic activity from at least $94 \mathrm{Ma}$ to $42 \mathrm{Ma}$ (Maluski et al., 1982; Debon et al., 1986; Schärer et al., 1984; Xu et al., 1985; Copeland et al., 1995; Quidellieur et al., 1997; Harrison et al., 2000; Mo et al., 2005), or even to as young as $30 \mathrm{Ma}$ (Harrison et al., 2000), with most dated localities having Paleocene or Eocene ages.

\section{Samples and analytical methods}

In this study, twenty-five out of $150+$ granitoids sampled from several transverses across the Gangdese Batholith were subjected to zircon separations by combining heavy-liquid and magnetic techniques and then to zircon $\mathrm{U}-\mathrm{Pb}$ dating by using the sensitive highresolution ion microprobe (SHRIMP) method (Liu et al., 2006). The Gangdese zircons are mostly euhedral and show long to short prismatic forms, with average crystal lengths of $\sim 150-200 \mu \mathrm{m}$ and length-to-width ratios up to 3:1. Most zircons are transparent, colorless to slightly brown and show oscillatory zoning typical of magmatic growth (Hoskin and Schaltegger, 2003). Zircons with rounded or ovoid shape and complex internal textures are rare.

Zircon grains, together with a zircon $\mathrm{U}-\mathrm{Pb}$ standard (TEMORA; cf. Black et al., 2004), were cast in an epoxy mount, which was then polished to section the grains in half for analysis. Zircons were documented with transmitted and reflected light micrographs as well as cathodoluminescence images to reveal their internal structures, and the mount was vacuum-coated with an $~ 500 \mathrm{~nm}$ layer of highpurity gold. Measurements of $\mathrm{U}, \mathrm{Th}$, and $\mathrm{Pb}$ were conducted using the SHRIMP II ion microprobe at the Beijing SHRIMP Lab, Institute of Geology, Chinese Academy of Geological Sciences, with technical specifications essentially identical to those operated in the Australian National University (e.g., Black et al., 2004). U-Th-Pb isotope ratios were determined relative to the TEMORA standard zircon (with ${ }^{206} \mathrm{~Pb} /$ ${ }^{238} \mathrm{U}=0.0668$ corresponding to $417 \mathrm{Ma}$ ), and their absolute abundances were calibrated to other standard zircons SL13 and CZ3. Repeated analyses of the TEMORA standard were interspersed with those of unknown zircons. Measured compositions were corrected for common $\mathrm{Pb}$ using the ${ }^{204} \mathrm{~Pb}$-correction method.

\section{Analytical results}

The zircon dating results are presented as concordia diagrams in Fig. 2 and summarized in Table 1, with the detailed data set being listed in Appendix A. Given that in SHRIMP analysis precise age measurements using ${ }^{207} \mathrm{~Pb} /{ }^{235} \mathrm{U}$ and ${ }^{207} \mathrm{~Pb} /{ }^{206} \mathrm{~Pb}$ ratios are feasible usually only for Precambrian zircons, due largely to the fact that ${ }^{235} \mathrm{U}$ now comprises less than $1 \%$ of natural $U$ and relatively little ${ }^{207} \mathrm{~Pb}$ can be produced in the Phanerozoic (cf. Ireland and Williams, 2003), the weighted means of pooled ${ }^{206} \mathrm{~Pb} /{ }^{238} \mathrm{U}$ ages are taken to indicate crystallization ages of the young Gangdese rocks, which range from 

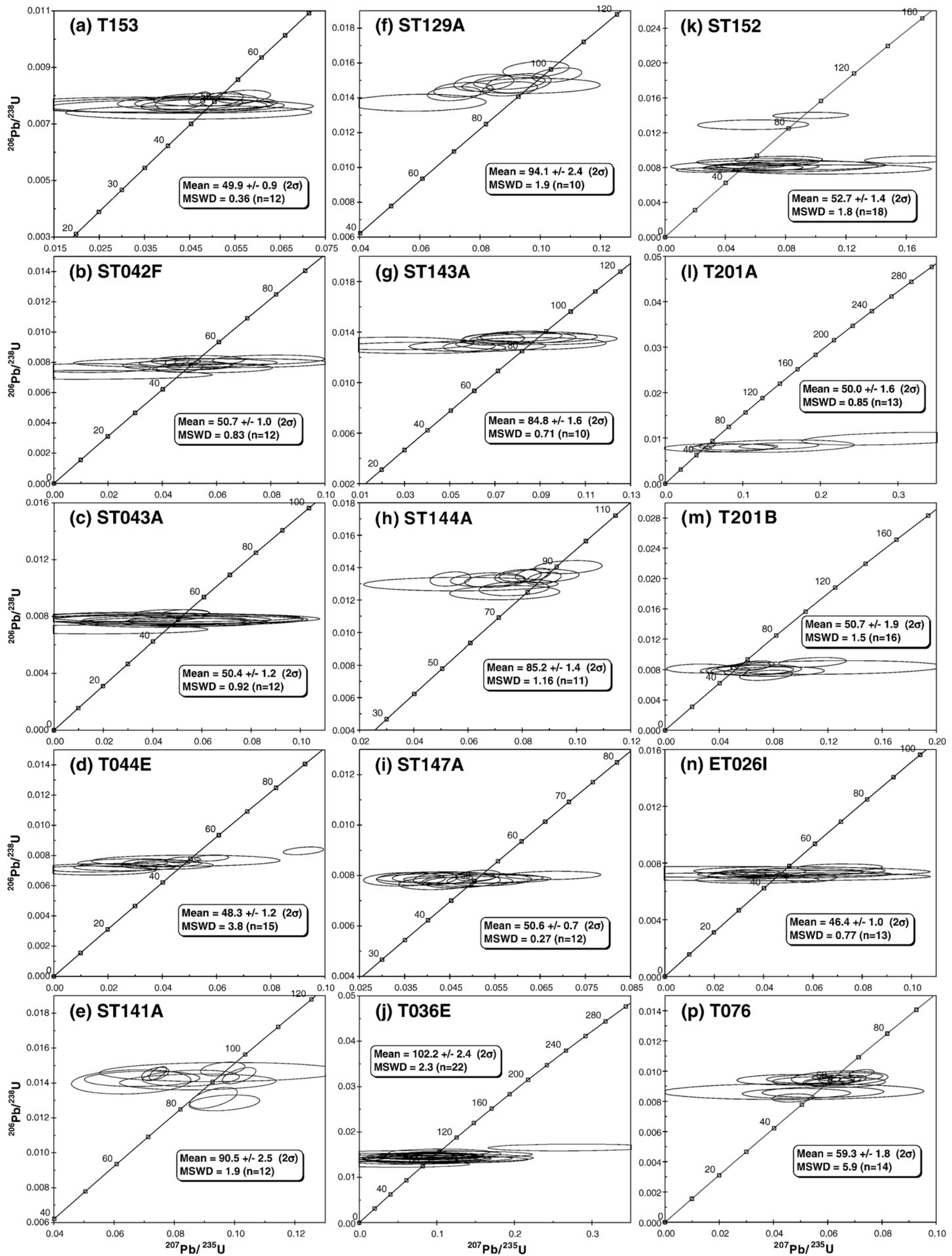

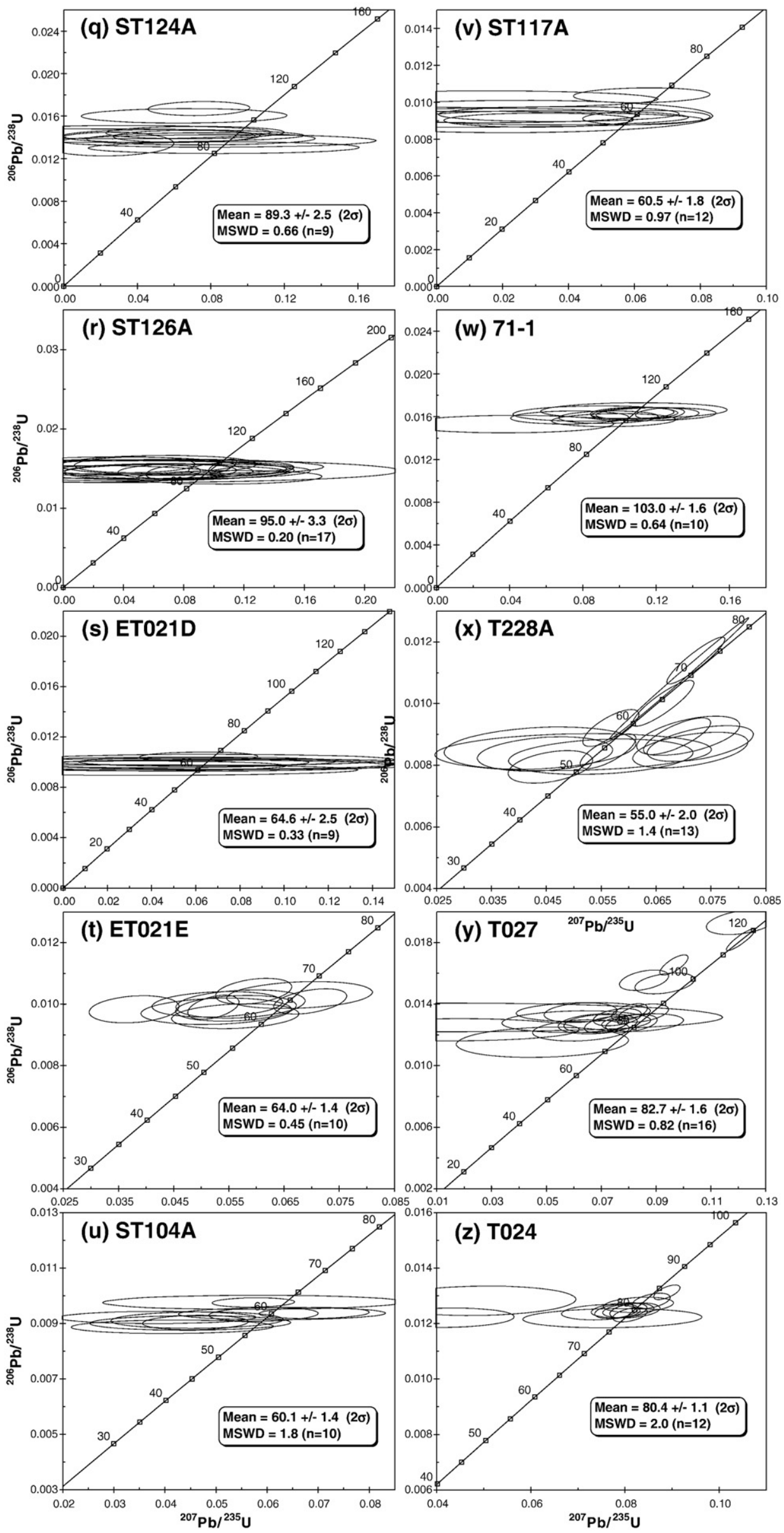
Table 1

Summary of sample localities and SHRIMP zircon U-Pb ages of the Gangdese Batholith, southern Tibet

\begin{tabular}{|c|c|c|c|c|c|c|c|c|}
\hline Sample & Locality & Longitude $\left({ }^{\circ} \mathrm{E}\right)$ & Latitude $\left({ }^{\circ} \mathrm{N}\right)$ & Elevation (m) & Rock type & $\mathrm{SiO}_{2}(\mathrm{wt} \%)^{\mathrm{a}}$ & Age $+/-2 \sigma$ & \\
\hline T153 & Cuoqin-Dajia Co & 85.41 & 30.13 & 5492 & Diorite & 53.4 & 49.9 & 0.9 \\
\hline ST042F & Xietongmen & 88.23 & 29.45 & 4022 & Granodiorite & 63.9 & 50.7 & 1.0 \\
\hline ST043A & Xietongmen & 88.23 & 29.45 & 4022 & Granodiorite & 63.6 & 50.4 & 1.2 \\
\hline T044E & Nanmulin & 89.08 & 29.49 & 3925 & Gabbro & 52.1 & 48.3 & 1.2 \\
\hline ST141A & Xigaze-Nanmulin & 89.09 & 29.40 & 3860 & Gabbro & 50.6 & 90.5 & 2.5 \\
\hline ST129A & Dazhuka & 89.63 & 29.39 & 3840 & Diorite & 57.7 & 94.1 & 2.4 \\
\hline ST143A & Dazhuka-Nimu & 89.81 & 29.31 & 3775 & Diorite & 57.6 & 84.8 & 1.6 \\
\hline ST144A & Dazhuka-Nimu & 89.94 & 29.32 & 3740 & Diorite & 59.3 & 85.2 & 1.4 \\
\hline ST147A & Nimu & 90.18 & 29.40 & 3740 & Diorite & 53.9 & 50.6 & 0.7 \\
\hline T036E & Nimu-Quxu & 90.31 & 29.32 & 3712 & Diorite & 56.6 & 102.2 & 2.4 \\
\hline ST152A & Quxu Bridge & 90.69 & 29.33 & 3595 & Gabbro & 49.7 & 52.7 & 1.4 \\
\hline T201A & Quxu & 90.73 & 29.35 & 3573 & Gabbro-enclave & 51.4 & 50.0 & 1.6 \\
\hline Т201B & Quxu & 90.73 & 29.35 & 3573 & Granodiorite & 62.1 & 50.7 & 1.9 \\
\hline ET026I & Quxu/Nanmu & 90.87 & 29.48 & 3816 & Granodiorite & 66.5 & 46.4 & 1.0 \\
\hline T076 & Lhasa & 91.22 & 29.67 & 3691 & Granite & 69.9 & 59.3 & 1.8 \\
\hline ST124A & Sangyi & 91.44 & 29.30 & 3562 & Granodiorite & 62.8 & 89.3 & 2.5 \\
\hline ST126A & Sangyi & 91.46 & 29.30 & 3602 & Diorite & 56.2 & 95.0 & 3.3 \\
\hline ET021D & Qulong & 91.63 & 29.69 & 4149 & Granite & 71.6 & 64.6 & 2.5 \\
\hline ET021E & Qulong & 91.63 & 29.69 & 4149 & Diorite & 55.1 & 64.0 & 1.4 \\
\hline ST104A & Zedong & 91.81 & 29.27 & 3566 & Granodiorite & 65.6 & 60.1 & 1.4 \\
\hline ST117A & Sangri & 92.19 & 29.25 & 3576 & Granite & 69.3 & 60.5 & 1.8 \\
\hline $71-1$ & Langxian & 93.16 & 29.04 & 3109 & Granodiorite & 64.7 & 103.0 & 1.6 \\
\hline $\mathrm{T} 027^{\mathrm{b}}$ & Langxian-Lilong & 93.32 & 29.00 & 3092 & Granodiorite & 66.5 & 82.7 & 1.6 \\
\hline T024 & Lilong & 93.75 & 29.14 & 3022 & Granodiorite & 69.5 & 80.4 & 1.1 \\
\hline T228A & Baiba & 94.01 & 29.76 & 3106 & Granite & 73.3 & 55.0 & 2.0 \\
\hline
\end{tabular}

a Data from Wen (2007).

b Data from Wen et al. (in press).

$103.0 \pm 1.6$ to $46.4 \pm 1.0 \mathrm{Ma}$ (Table 1 and Fig. 2). In Fig. 2, the feature of less precise ${ }^{207} \mathrm{~Pb} /{ }^{235} \mathrm{U}$ measurements is clearly shown by apparently larger horizontal variations in the age ellipses. This may also be responsible for the negative and positive discordant features in some zircons particularly when their $U$ contents are low, e.g., samples ST143A and T201A (Fig. 2: g and 1; with many zircons containing $\mathrm{U}<100 \mathrm{ppm}$, see Appendix A), which would cause even more difficulties in measuring and correcting ${ }^{207} \mathrm{~Pb}$. The ${ }^{206} \mathrm{~Pb} /{ }^{238} \mathrm{U}$ ages are reported with analytical uncertainties at two-standard deviation $(2 \sigma)$ or $95 \%$ confidence level, and the mean values are shown in Fig. 1 to depict the distribution of our zircon dating results. Although the measured $U$ and Th concentrations are highly variable, ranging from 21 to 3495 and from 12 to 9890 ppm, respectively, they correlate with each other in general so that yield Th/U ratios from $\sim 0.3$ to 2.8 in accordance with those of igneous zircons (Belousova et al., 2002; Hoskin and Schaltegger, 2003). Nearly all zircons dated are co-magmatic, only in two samples (T027 and T228A) grains of apparently older inherited zircons are observed (see Appendix A). Below we present emplacement ages of the Gangdese Batholith by comparing our SHRIMP zircon $\mathrm{U}-\mathrm{Pb}$ results together with published age data. Disregarding the continuity of the Batholith, it is divided, from west to east, into the following segments for the convenience of discussion.

\subsection{The Coqin-Dajia Co segment}

From this segment we have only one sample dated that is a diorite (T153, Table 1) and yielded a ${ }^{206} \mathrm{~Pb} /{ }^{238} \mathrm{U}$ age of $49.9 \pm 0.9 \mathrm{Ma}$ (Fig. 2a). This Paleogene age is comparable to the $\mathrm{Ar}-\mathrm{Ar}$ date of $45.4 \pm$ 1.2 Ma (Yin et al., 1999) for hornblende separates from the Kailas intrusive complex in the west (Fig. 1). To further west, in the Xungba area (Fig. 1), zircon U-Pb ages of ca. 120 and 116 Ma have been reported for two granites (Miller et al., 1999), implying a stage of Early Cretaceous plutonism in the western extension of the
Gangdese belt. It is also noted that Cretaceous to Late Jurassic zircon $\mathrm{U}-\mathrm{Pb}$ ages (ca. 100-150 Ma) have been published for several granites from Coqin and adjacent areas (Murphy et al., 1997; Ding and Lai, 2003), but these rocks belong to the northern magmatic belt (Fig. 1).

\subsection{The Xietongmen-Nanmulin segment}

Without reliable preexisting age data from this segment, three out of four samples dated in this study gave coeval $\mathrm{U}-\mathrm{Pb}$ ages around $50 \mathrm{Ma}$ (Fig. 2, b-d) and the other yielded ca. $90 \mathrm{Ma}$ (Fig. 2e). These are 2 granodiorites and 2 gabbros (Table 1 ) that, as the remaining undated samples from this segment, possess calc-alkaline and I-type geochemical characteristics (Wen et al., 2003; Wen, 2007). While ages of the former three samples demonstrate an important stage of early Eocene magmatic activity in this region, the last sample may be correlated to its eastern segment (see next section) where plutonism appears to have been prevailing during the Late Cretaceous.

\subsection{The Dazhuka-Nimu segment}

Five samples were dated from this segment. Four of them yielded Late Cretaceous U-Pb ages between ca. 102 and 84 Ma (Fig. 2, f-h and j), whereas the other that were recovered from the middle part (Fig. 1) gave a much younger age of $\mathrm{ca} .50 \mathrm{Ma}$ (Fig. 2i). All the five samples are diorites (Table 1), representing the most abundant rock type in the Gangdese Batholith. Age data available for the Gangdese rocks from the Dazhuka area were only Late Cretaceous, including: (1) two zircon U-Pb dates of ca. 94 Ma obtained by conventional method (Schärer et al., 1984), (2) four ArAr dates between 93 and $113 \mathrm{Ma}$ (Maluski et al., 1982), and (3) two Rb-Sr isochron dates of 88 and $93 \mathrm{Ma}$ (Debon et al., 1986). Our results, hence, identify for the first time the presence of an early Eocene body from this segment that has been documented for long only with the occurrence of Cretaceous intrusions. 


\subsection{The Quxu-Lhasa segment}

All of the five dated samples from this segment yielded Paleogene ages (Table 1 and Fig. 2, k-p), supporting previous studies (Jin and $\mathrm{Xu}$, 1984; Schärer et al., 1984; Xu et al., 1985; Debon et al., 1986; Copeland et al., 1995; Mo et al., 2005) in which magmatic ages > 65 Ma have never been reported. An apparent discrepancy, nonetheless, is observed from the Quxu body, a "classical" exposure that has been widely used to exemplify the I-type lithology and geochemistry of the Gangdese Batholith since the Sino-French pioneer study. This famous body was dated by Schärer et al. (1984) using conventional U-Pb method on multiple zircon grains that yielded crystallization ages of ca. $41 \mathrm{Ma}$, the youngest among ages ever obtained for the Gangdese Batholith. Our SHRIMP results, however, indicate that the emplacement should have occurred earlier at around $50 \mathrm{Ma}$. These include ${ }^{206} \mathrm{~Pb} /{ }^{238} \mathrm{U}$ ages of (1) $50.7 \pm 1.9 \mathrm{Ma}$ for a granodiorite from the Quxu "type locality", (2) $50.0 \pm$ 1.6 Ma for its mafic enclave, (3) $52.7 \pm 1.4$ Ma for a gabbro from the Quxu bridge, and (4) $46.4 \pm 1.0 \mathrm{Ma}$ for a granodiorite from $15 \mathrm{~km}$ north of Quxu village (Fig. 1). Our results are consistent with recently reported zircon U$\mathrm{Pb}$ age data (ca. 49-50 Ma) from the Quxu intrusion acquired also by the SHRIMP method (Mo et al., 2005). Judging from the data set published in Schärer et al. (1984), their underestimated ages resulted probably from less precise mass spectrometry and/or common lead correction.

The remaining sample is a granite from the Lhasa body that crops out $\sim 10 \mathrm{~km}$ north of Lhasa city (Fig. 1 ) and yielded a crystallization age of $59.3 \pm$ $1.8 \mathrm{Ma}$ (Fig. 2p). This result is, again, older than the conventional zircon U$\mathrm{Pb}$ date (ca. $53 \mathrm{Ma}$ ) reported by Schärer et al. (1984) but in coincidence with a biotite $\mathrm{Ar}-\mathrm{Ar}$ date $(62 \pm 1 \mathrm{Ma})$ reported for the intrusive body (Copeland et al., 1995). It is therefore inferred that the Lhasa body was emplaced ca. 10 m.y. earlier than the Quxu body. Other published age data from this segment include: (1) two Rb-Sr dates of ca. 56 and 59 Ma from Dagze and Gurong, respectively (Jin and Xu, 1984), and (2) a zircon U-Pb date of ca. $50 \mathrm{Ma}$ (Xu et al., 1985) and two Rb-Sr dates of ca. 47-49 Ma (Xu et al., 1985; Debon et al., 1986) from Yangbajing.

\subsection{The Sangyi-Zedong segment}

We dated six samples from this segment. Two of them from Sangyi in the western part gave Cretaceous ages of ca. 89 and 95 Ma (Fig. 2, q and r), while remaining four from areas around Zedong (Fig. 1) are all of early Paleocene ages between ca. 65 and $60 \mathrm{Ma}$ (Fig. 2, S-v). In the Zedong terrane, exposed within the northern Yarlu-Zangpo suture, a zircon U-Pb date of 92.6 \pm 1.8 Ma was reported for Gangdese-derived granite block (McDermid et al., 2002). East of the Zedong township, the Gangdese Batholith has been intensively dated by Harrison et al. (2000) using $\mathrm{Ar}-\mathrm{Ar}$ method on various mineral phases, among which the $\mathrm{Ar}-\mathrm{Ar}$ ages of hornblendes appear restricted to a small range from ca. 67 to $63 \mathrm{Ma}$, slightly older than but in general agreement with our zircon U$\mathrm{Pb}$ ages. However, Harrison et al. (2000) also conducted zircon ion microprobe dating on the rocks and reported two sets of much younger $\mathrm{U}-\mathrm{Pb}$ dates at $48.9 \pm 0.8$ and $42.5 \pm 1.0 \mathrm{Ma}$, and the latter is now the youngest reported crystallization age over the entire Gangdese Batholith. Moreover, Harrison et al. (2000) reported a zircon U-Pb age of ca. $30 \mathrm{Ma}$ for a deformed intrusion from the hanging wall of the Gangdese Thrust in the Zedong area, based on which they argued the Gangdese magmatism to have lasted until this time. The intrusion, however, is part of the Yaja granodiorite that is marked with adakitic geochemical characteristics and belongs to the post-collisional magmatic suite resulting from partial melting of thickened mafic lower crust underneath southern Tibet (Chung et al., 2003, 2005).

\subsection{The Langxian-Bayi segment}

Four dated samples from this easternmost segment of the Gangdese Batholith involve a variety of rock types and geochemical characteristics, including particularly the discovery of Late Cretaceous "adakitic" magmatism in the region. These rocks are (1) a granodiorite (71-1) from Langxian that shows, as most of Gangdese rocks throughout the Batholith, typical I-type, calc-alkaline petrochemical compositions and yielded ${ }^{206} \mathrm{~Pb} /{ }^{238} \mathrm{U}$ age of $103.0 \pm 1.6 \mathrm{Ma}$ (Fig. $2 \mathrm{w}$ ), (2) two granodiorites (T027 and T024) from an intrusion between Langxian and Lilong (Fig. 1) that exhibit adakitic geochemical signatures (Wen et al., in press) with U-Pb ages of ca. 83-80 Ma (Fig. 2, y and z), and (3) a calc-alkaline granite (T228A) from Baiba, $~ 10 \mathrm{~km}$ west of Bayi city (Fig. 1) dated at 55.0 \pm 2.0 Ma (Fig. 2x).

In a study focused on the thermal history of the Renbu-Zedong Thrust, which crosscuts the Gangdese Batholith, Quidellieur et al. (1997) reported zircon U-Pb ages of 12 granitoids from a NE-SW section located $\sim 20 \mathrm{~km}$ east of Langxian, between the localities of our two samples 71-1 and T027 dated at ca. 103 and 83 Ma, respectively (Fig. 1 and Table 1). These U-Pb ages range from ca. 108 to $82 \mathrm{Ma}$, except a younger date of $68 \pm 4$ Ma based on seven zircon grains. There were no geochemical data reported for these granitoids so it is uncertain if some of them are of adakitic compositions. Our work from the same area (Wen et al., in press) suggested that the adakitic magmatism may not have lasted for long and took place only in a short period (ca. 83-80 Ma) within a restricted region.

Around Bayi, five SHRIMP zircon U-Pb ages from 64 to 44 Ma have been reported for the Gangdese granitoids (Booth et al., 2004). To the east, within the Namche Barwa syntaxis, numbers of zircon $\mathrm{U}-\mathrm{Pb}$ and mineral $\mathrm{Ar}-\mathrm{Ar}$ ages from 79 to 65 Ma have been published for deformed/undeformed Gangdese type granitic rocks (Burg et al., 1998; Ding et al., 2001; Booth et al., 2004; Geng et al., 2006). How should the Gangdese Batholith be correlated further eastward over the Namche Barwa remains problematic, but zircon $\mathrm{U}-\mathrm{Pb}$ age results obtained so far for calc-alkaline granitoids from the Bomi area (Fig. 1) indicate that the rocks were emplaced either in the late Early Cretaceous (ca. 125$108 \mathrm{Ma}$ ) or in the Paleocene (ca. 63-58 Ma) (Booth et al., 2004; Liang et al., in press). Despite the geologic complexities in and around the Namche Barwa, the age data from Bayi and nearby regions from the easternmost part of the Gangdese Batholith suggest the presence of a Paleogene stage of magmatism that postdates the Late Cretaceous intrusion near Langxian in the southwest.

\section{Discussion}

\subsection{The Gangdese magmatic evolution}

Our new age results are compiled in the histogram (Fig. 3, a-b) for a better understanding of the temporal spectrum of the Gangdese magmatism. Furthermore, we include age data of granitoids from the northern magmatic belt (Fig. 3; a and c), and those of the Linzizong and associated volcanic rocks (Fig. 3d), within the Lhasa terrane for comparison and discussion on the magmatic evolution and tectonic implications.

As a whole, our zircon SHRIMP U-Pb results show good accordance with the combined literature age data of the Gangdese Batholith (Fig. 3a). This entitles us to use our data set $(n=25)$ to plot an age probability curve for the Gangdese plutonism, which delineates two distinct plutonic stages during the Late Cretaceous (ca. 103-80 Ma) and early Paleogene (ca. 65$46 \mathrm{Ma}$ ), respectively (Fig. 3a). In between, from ca. 80 to $70 \mathrm{Ma}, \mathrm{a}$ noticeable magmatic "gap" or quiescent period is revealed. If combined with literature data, durations of the Cretaceous and Paleogene stages may be further expanded to be around 120-80 and 69-43 Ma, respectively. Note that the oldest age (ca.120 Ma) is observed only from Xungba in the west (Miller et al., 1999) and the youngest (ca. $43 \mathrm{Ma}$ ) is from Zedong (Harrison et al., 2000), excluding the two presumably underestimated ages (ca. $41 \mathrm{Ma}$ ) for the Quxu intrusion (Fig. 3b). Two additional important observations are (1) the early stage ended with a granodiorite intrusion of adakitic composition at ca. 83-80 Ma (Wen et al., in press), and (2) the latter stage appears to have been spatially more widespread and reached a culmination with regional activities around $50 \mathrm{Ma}$ (Fig. 3a). 

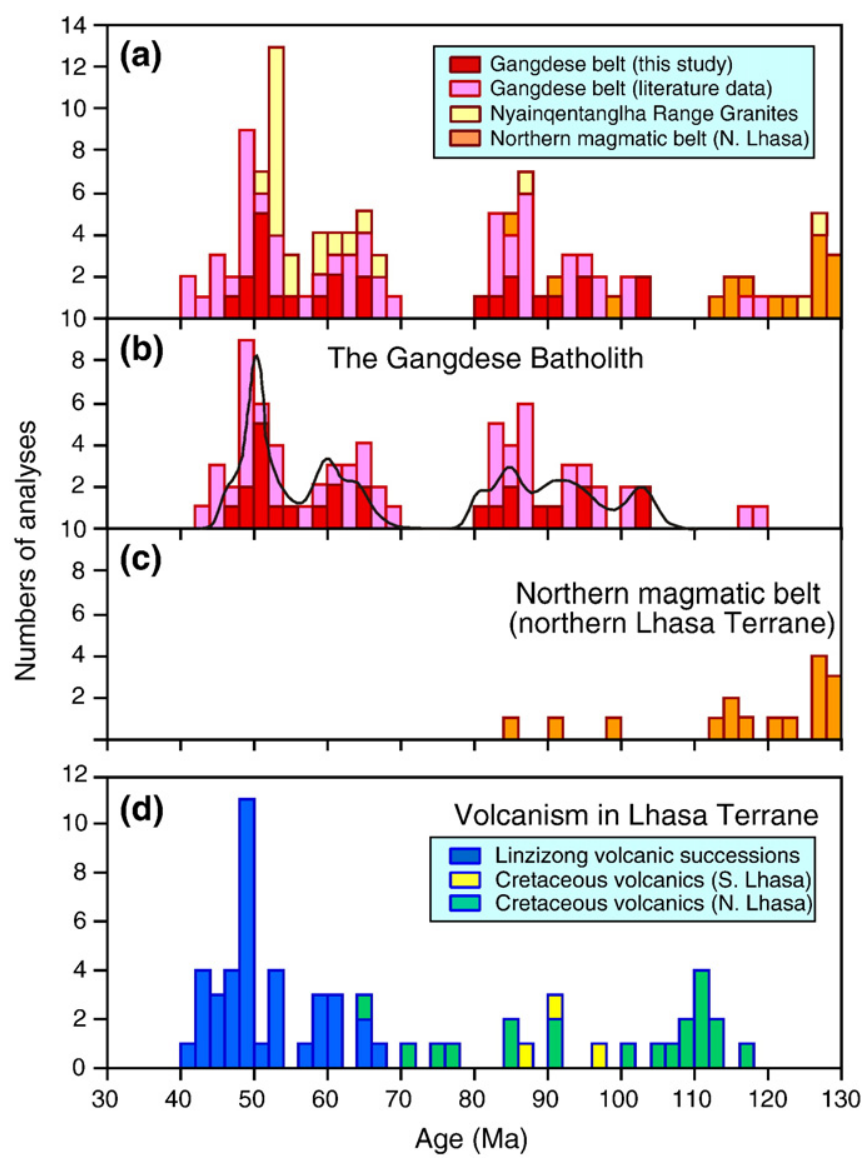

Fig. 3. (a) Histogram of compiled age data of the Gangdese and associated plutonic rocks in the Lhasta terrane. Data sources include (1) the Gangdese belt: this study $(n=25)$ and all literature data discussed in the text, (2) S-type granites from the Nyainqentanglha Range (Hu et al., 2003; Kapp et al., 2005a), and (3) granitoids from the northern magmatic belt, the northern Lhasa terrane (Harris et al., 1988, 1990; Murphy et al., 1997; Ding and Lai, 2003; Chu et al., 2006; Kapp et al., 2007a,b; and our unpubl. data). Age spectra of (1) and (3) are shown separately in (b) and (c) to better reveal the proposed southward shift in magmatic activity in the Lhasa terrane. Note that in (b) two presumably too young zircon ages of ca. 41 Ma previously reported for the Quxu body (see text for discussion) were removed and the age probability curve was constructed using only SHRIMP zircon $\mathrm{U}-\mathrm{Pb}$ age data of this study. (d) Histogram of age data of the Linzizong and associated volcanic rocks in the Lhasa terrane, compiled by Lee (2007), for comparison.

Chu et al. (2006) recently argued that within the southern Lhasa terrane there were three discrete stages of Gangdese magmatism occurring in the Jurassic, Cretaceous and Paleogene, respectively, owing to the long-lasting, northward Neotethyan subduction. While the Jurassic stage of magmatism remains poorly studied so that its temporal/spatial relationships with the latter stages are unclear, several lines of evidence for a widespread occurrence of the Jurassic magmatism include (1) strata-intercalated basaltic to rhyolitic volcanic rocks in the uppermost Triassic-Middle Jurassic Yeba Formation, exposed in the eastern Gangdese belt (Pan et al., 2004; Yin and Grant-Mackie, 2005; Zhu et al., 2008), (2) abundant Jurassic detrital zircons observed in Cretaceous tuffaceous sandstone, the southern Lhasa terrane and the Yarlu-Zangpo river sediments (Liang et al., 2004), and (3) abundant Jurassic inherited zircons from S-type granites in the southern part of the northern magmatic belt (Chu et al., 2006; Kapp et al., 2005a).

On the northern magmatic belt of the Lhasa terrane (Fig. 1), Chu et al. (2006) further argued that extensive, but dominantly crustallyderived, magmatism has been active also by Early Jurassic time. Discussion of the Jurassic records, however, is beyond the scope of this paper, here we only pile up those $<130 \mathrm{Ma}$ ages onto the Gangdese data set in the histogram (Fig. 3). Note that a large portion of the data (19 out of 37 ages plotted) is from Kapp et al. (2005a), a study focused in a small area within the Nyainqentanglha Range locating in the southern margin of the northern magmatic belt (Fig. 1). Taking together additional two Paleocene ages from the Nyainqentanglha Range (Hu et al., 2003), the granite intrusions appear to have restarted at ca. $66 \mathrm{Ma}$, after a long quiescence since ca. $88 \mathrm{Ma}$, and lasted until ca. 50 Ma with a likely peak activity around $53 \mathrm{Ma}$ (Fig. 3a).

Our new $\mathrm{Ar}-\mathrm{Ar}$ and zircon $\mathrm{U}-\mathrm{Pb}$ age results for the Linzizong and associated volcanic successions from a large area $\left(85^{\circ} \mathrm{E}\right.$ to $93^{\circ} \mathrm{E}$ and $29^{\circ} \mathrm{N}$ to $32^{\circ} \mathrm{N}$; Lee, 2007; Lee et al., 2007), together with literature data (Fig. 3d), suggest two discrete episodes of volcanic eruption in consistency with the intrusive records. These are (1) a more widespread Cretaceous episode (ca. 120-65 Ma) occurring in both the northern and southern (Gangdese) magmatic belts, and (2) an intense, but geographically confined, Paleogene episode (ca. 64-43 Ma) that took place only in the south. The age data, moreover, led to a significant conclusion that there existed southward migration and intensification of the volcanism in the Lhasa terrane. The latter is marked with a volcanic culmination or "flare-up" event around $50 \mathrm{Ma}$ (Fig. 3d) that, again, matches with the Gangdese intrusive records.

The idea of Paleocene-Eocene volcanic flare-ups, i.e., the principal Linzizong eruptions, has long been noted. Yin et al. (1994), for example, had postulated how the Neotethyan slab rollback may have caused this event based on broad observations across southern Tibet. The "precise" timing of the flare-up event, however, cannot be constrained until our studies. We address also that volcanics formed during the flare-up period, relative to the main rock type of a calcalkaline nature in the Linzizong successions, show significant geochemical variations from low-K tholeiitic and calc-alkaline to shoshonitic compositions (Lee, 2007). Associated plutonic rocks include I-type granitoids emplaced all over the Gangdese Batholith and S-type granites in the Nyainqentanglha Range. Such magmatic flare-ups, and the heterogeneities in lithologies and geochemical compositions, require a specific mechanism, which we attribute to breakoff of the subducted Neotethyan oceanic slab (see below), rather than its continuous subduction under southern Tibet.

\subsection{Tectonic interpretations and implications}

The above age data, together with petrochemical constraints derived from our relevant works on the Gangdese Batholith and Linzizong volcanic successions, enable us to propose a tectonomagmatic evolution model from ca. 100 to $45 \mathrm{Ma}$ for southern Tibet. The model that will be detailed in the following may be depicted as 4 sequential scenarios in Fig. 4. Note that while scenarios 1 and 3 (i.e., Fig. 4a and c, respectively) represent generalized pictures for the two stages of Gangdese magmatism, we address in scenarios 2 and 4 (Fig. 4b and d) the particular events at ca. 80 and 50 Ma marked by cessation of the early magmatic stage with adakitic intrusion and regional igneous "flare-ups" in the southern Lhasa terrane, respectively. With the awareness that some of our interpretations may be non-unique, comparisons with existing models (e.g., Coulon et al., 1986; Ding et al., 2003; Kapp et al., 2005b, 2007b) will also be addressed.

\subsection{1. $100 \mathrm{Ma}$ (Fig. 4a)}

We start our model from this time because the oldest magmatic record of the Cretaceous Gangdese is ca. $103 \mathrm{Ma}$ (Fig. 3b) and, even if taking the emplacement ages of ca. 120-116 Ma from Xungba in its western extension into consideration, no magmatism between ca. 116 and $103 \mathrm{Ma}$ has been reported over the Gangdese belt (Fig. 3). Thus, the magmatic, and tectonic, evolution in the southern Lhasa terrane before this time span remains rather uncertain. Since ca. $100 \mathrm{Ma}$, it is now evident that the Gangdese had been activated with extensive intrusions and associated eruptions that show arc-lava type geochemical systematics (Wen et al., 2003; Chu et al., 2006; Wen, 2007) 
S
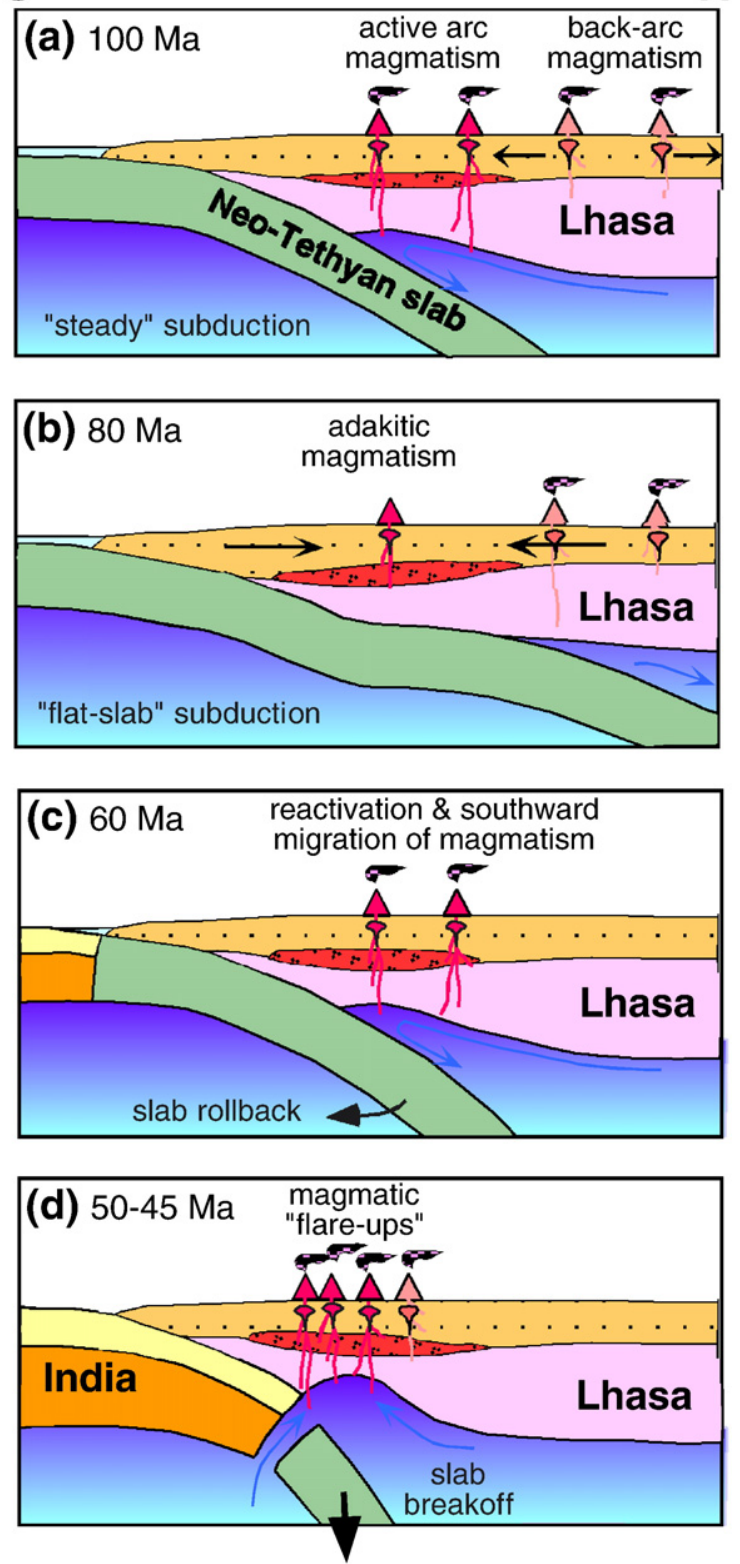

Fig. 4. A sequential tectonomagmatic evolution of southern Tibet during ca. 100 and 50 $45 \mathrm{Ma}$, illustrated by the north-south cross sections through time. The proposed sequences are discussed in the text.

as those observed in the circum-Pacific regions. Consisting overwhelmingly of I-type lithologies, the rocks are furthermore characterized by low Sr and high Nd isotopes (Harris et al., 1988; Wen et al., 2003; Wen, 2007), as well as high Hf isotopes in their igneous zircons (Chu et al., 2006; Chu, 2006), which suggest a significant contribution from the juvenile mantle source in the magma genesis, accompanied by intense basaltic underplating in the lower crust that remelted subsequently to form substantial felsic intrusions (Wen, 2007).

The northern magmatic belt, by contrast, seems to have become waning after a stronger activity between ca.130 and $100 \mathrm{Ma}$ (Fig. 3). Such southward migration and enhancement in magmatism, arguably with a magmatic gap in the Gangdese belt from ca. 116 to $103 \mathrm{Ma}$, are just like what happened in the early Paleogene (described above) that could be interpreted by rollback of the Neotethyan slab from a shallower subducting angle or "flat" subduction (see below). If this was the case, the rollback could have not only enhanced the corner flow in the mantle wedge to cause the extensive Gangdese arc magmatism sourced predominantly from the ascended asthenosphere (=juvenile mantle), but also resulted in an extensional setting in the backarc region that accounted for the nonmarine deposition (i.e., the Lhunzhub Member) of the Takena Formation (cf. Yin et al., 1988) and associated rapid subsidence beginning late Albian time (ca. 105$100 \mathrm{Ma}$ ) or the latest Early Cretaceous (Leier et al., 2007). While Leier et al. (2007) attributed deposition of the Lhunzhub Member to flexural subsidence in a back bulge depozone during contraction, we note that a backarc extension setting has also been proposed for the formation of upper sequences in the nearby Lower Cretaceous Asa basin in the northern Lhasa terrane (Zhang et al., 2004).

\subsection{2. $80 \mathrm{Ma}$ (Fig. $4 b)$}

After a period of "steady" subduction responsible for the extensive Gangdese intrusions during ca. 100 and $85 \mathrm{Ma}$, we propose a "flatslab" subduction that started no later than ca. 83-80 Ma and resulted in a major stage of contractional tectonic regime lasting to the latest Cretaceous (ca. 70-65 Ma) in southern Tibet. This is based upon two lines of independent evidence, which are (1) the occurrence of adakitic granodiorites in the Gangdese Batholith around 83-80 Ma, and (2) cessation of the Takena deposition from ca. 90-80 Ma followed by regional folding and erosion (see below). The idea of a relatively flatter, or "shallow-angle", Neotethyan subduction in Cretaceous time, first envisioned by Coulon et al. (1986), has been generally accepted by more recent workers (e.g., Ding et al., 2003; Chung et al., 2005; Kapp et al., 2005b, 2007a,b). Our model, however, is the first that specifies the time span of the flat-slab subduction.

Adapted from a separate publication of the detail (Wen et al., in press), we here summarize our work on the adakitic granodiorites from the eastern Gangdese segment. The rocks, dated at $82.7 \pm 1.6$ and $80.4 \pm 1.1 \mathrm{Ma}$ (Fig. 2, y and $\mathrm{z}$ ), are peraluminous granodiorites with adakitic geochemical features, marked by apparently lower $\mathrm{Y}$ and HREE, and thus higher Sr/Y and La/Yb, than the other Gangdese and common arc lavas. In addition to the principal mineral constituents, i.e., hornblende, feldspar and quartz, these intrusives contain magmatic epidote and celadonitic muscovite that imply a deep intrusion/ crystallization coupled with rapid exhumation (cf. Zen, 1985; Schmidt and Poli, 2004), with the emplacement $P-T$ conditions being estimated to be $\sim 730-765{ }^{\circ} \mathrm{C}$ and $\sim 0.6-1.1 \mathrm{GPa}$ (Anderson, 1996), corresponding to $\sim 22-40 \mathrm{~km}$ in the middle to lower crust. Our trace element modeling suggests a magma origin by partial melting of garnetbearing amphibolites at pressures $\geq 1.2 \mathrm{GPa}$, which we interpret on the basis of whole-rock $\mathrm{Sr}$ and $\mathrm{Nd}$ isotopes $\left[I_{\mathrm{Sr}}=\sim 0.7045 ; \varepsilon_{\mathrm{Nd}}(T)=+1-+3\right]$ and 5 grains of inherited zircons aged ca. 100-123 Ma in sample T027 (Appendix A) to be dominantly the juvenile lower crust produced by Cretaceous basaltic underplating above the mantle wedge during the Gangdese arc magmatism.

The adakite generation requires not only melting of a newly underplated basaltic source, but also the presence of a thick crust so that the underplates may transform to garnet-bearing amphibolites or even eclogites. Exemplary analogues include the modern Central Andes (Kay and Mpodozis, 2001) and the Late Cretaceous Laramide orogeny in southern North America (Saleeby, 2003), in both cases flat subduction has been documented. As exemplified by the Andes, flattening of the subducting slab could not only tectonically thicken the crust but also squeeze out the mantle wedge, and thus terminate the arc magmatism in the volcanic front region with adakites being generated as the ending phase (Kay and Mpodozis, 2001; Booker et al., 2004). Mimicking scenarios are observed here from southern Tibet, i.e., the Cretaceous Gangdese activity ceased with adakitic intrusion followed by a magmatic gap. We therefore propose that the region underwent a combined magmatic and tectonic thickening of the crust above the mantle wedge, with the former owing to extensive mafic magma underplating and the latter to the subsequent flat subduction. In the Andes, flat subduction occurs as oceanic plateau, seamount or 
ridge is being subducted (Gütscher et al., 2000). Within the Neotethyan oceanic basin, we envision these structural features to have been common because remnants of them have been identified within the Yarlu Tsangpo suture (e.g., Aitchison et al., 2004; DuboisCote et al., 2005; Dupuis et al., 2005).

Our model provides an alternative interpretation on why the Takena Formation stopped deposition at ca. $90-80 \mathrm{Ma}$ and experienced a period of folding and erosion during ca. 80 and $70 \mathrm{Ma}$ (Yin et al., 1988; Leier et al., 2007), before the restart of nonmarine deposition in the southern Lhasa terrane accompanied by the Paleogene Linzizong volcanism (Mo et al., 2005; He et al., 2007). Moreover, Late Cretaceous records of crustal deformation and shortening over the Lhasa terrane (e.g., England and Searle, 1986; Ratschbacher et al., 1993; Murphy et al., 1997; Yin and Harrison, 2000; Kapp et al., 2007a,b) may be interpreted as the result of an Andean- or "Pacific-type" (Maruyama, 1997) accretionary orogeny that occurred during this specific time interval in southern Tibet related to the flat subduction. Analogous to the Central Andes, which has high surface elevation associated with a thick crust and well-developed foldand-thrust belt in the retroarc region (Kay and Mpodozis, 2001), it is rational to further argue that there had existed a high, but relatively narrow, mountain range in southern Tibet prior to the collision of India with this part of Asia.

\subsection{3. $60 \mathrm{Ma}$ (Fig. 4c)}

A rollback or steepening of the Neotethyan subducting slab around Cretaceous-Tertiary time has been postulated since the pioneer work by Coulon et al. (1986) and remains widely consented by recent workers (Ding et al., 2003; Chung et al., 2005; Kapp et al., 2005b, 2007b). We argue here that the onset timing of this slab rollback should be slightly older than, or roughly coincident with, the Gangdese magmatic rejuvenation that, as described, evolved from ca. 68-65 Ma as a crucial component in the southward migration and intensification of plutonism as well as volcanism in the Lhasa terrane.

Consisting also of I-type lithologies, the Gangdese rocks of this stage show whole-rock geochemistry and $\mathrm{Sr}-\mathrm{Nd}$ isotope, and zircon's Hf isotope (Chu et al., 2006), compositions that are all comparable to those of their Cretaceous predecessor. This, again, suggests a dominant juvenile mantle source. Our geochemical modeling (Wen, 2007), furthermore, supports the general notion (e.g., Mo et al., 2005) of intense basaltic magma underplating in the lower crust that remelted subsequently to cause substantial silicic magmatism. We ascribe these events to the Neotethyan slab rollback, which could have induced a southward migration of the asthenospheric convection and thus enhanced the corner flow and changed the thermal structure of the mantle wedge (cf. Chung et al., 2005).

Most recently, Kapp et al. (2007b) synthesized their works in southern Tibet and argued that a Cordilleran-style convergent margin was established there by ca. $105 \mathrm{Ma}$. They further proposed that contractional deformation and sedimentary records observed in areas near the city of Lhasa can be attributed to the development of a northward-propagating retroarc thrust belt that may have accommodated the significant north-south crustal shortening in the region before the reactivation of Gangdese magmatism from ca. $69 \mathrm{Ma}$, which is linked to removal of overthickened mantle lithosphere through either tectonic erosion by the subducting slab or gravitational foundering. It is noted that similar geodynamic scenarios have been invoked to interpret the temporal correlations between the arc magmatism and retroarc shortening in the western US Cordillera (e.g., Ducea, 2001).

\subsubsection{0-45 Ma (Fig. 4d)}

A major change in tectonic background between the two stages of Gangdese magmatism is the India-Asia collision, if one adopts the general notion that the collision started ca. 65-55 Ma (e.g., Searle et al., 1987; Butler, 1995; Lee and Lawver, 1995; Ding et al., 2005; Mo et al., 2005), despite further studies are needed to definitively test the possibilities of an earlier (>65 Ma; e.g., Yin and Harrison, 2000) or later (Oligocene; Aitchison et al., 2004) initiation of the collision. We here follow the argument by Chung et al. (2005) that adopted the general notion and attributed rollback of the Neotethyan subduction to the Indian approaching toward Asia. In the terminal stage of the Neotethyan subduction, or the beginning stage of the India-Asia collision that may have involved attempted continental subduction (cf. Chemenda et al., 2000), breakoff of the subducted Neotethyan oceanic slab from the adherent but more buoyant Indian continental lithosphere, as that proposed by Kohn and Parkinson (2002), would have taken place as a result of gravitational resettling and strain localization (Davies and von Blanckenburg, 1995; van de Zedde and Wortel, 2001). Sharing the conclusion reached from our parallel study on the Linzizong volcanism (Lee, 2007), we argue that in southern Tibet the Neotethyan slab breakoff took place at around $50 \mathrm{Ma}$ in the early stage of the IndiaAsia collision. Such a "shallow" breakoff, i.e., detachment of the subducted oceanic slab from its adherent continental lithosphere at shallow depths (van de Zedde and Wortel, 2001), is capable of causing partial melting in various sources including the ascended asthenosphere, the enriched lithospheric mantle, and even the overlying crust. Consequently, magmas generated would be of great compositional diversities (Davies and von Blanckenburg, 1995; van de Zedde and Wortel, 2001), which, as described above, is exactly the case observed in the igneous "flare-up" period.

Although the idea of slab breakoff at the end of the oceanic subduction of the Tethys is not new, we emphasize the importance of our age and petrochemical data that together make compelling evidence for such an event in southern Tibet. The slab breakoff, which eliminated slab pull, would have prevented the Indian cratonic mantle lithosphere from moving further downward as it is more refractory and so intrinsically more buoyant than the younger mantle lithosphere of the Lhasa terrane (Chung et al., 2005). Without anywhere for the Indian mantle lithosphere to go, the continuous northward impingement of India could have started causing distributed lithospheric thickening beneath southern Tibet. This eventually led to the cessation of the Gangdese/Linzizong magmatism and then the region evolved from a subduction-related to continental collision orogenic environment.

\section{Acknowledgments}

We thank H.-Y. Lee, Q. Qian and D.C. Zhu for field assistance, Y.B. Wang and $\mathrm{H}$. Tao for help with zircon analyses. We also appreciate the thorough and constructive reviews by Paul Kapp, an anonymous reviewer and the editor Bernard Bourdon that greatly improved the presentation of this paper, which benefited from financial supports by the National Science Council, Taiwan, ROC.

\section{Appendix A. Supplementary data}

Supplementary data associated with this article can be found, in the online version, at doi:10.1016/j.chemgeo.2008.03.003.

\section{References}

Aitchison, J.C., Davis, A.M., Ali, J.R., et al., 2004. Stratigraphic and sedimentary constraints on the age and tectonic evolution of the Neotethyan ophiolites along the Yarlung Tsangpo suture zone, Tibet. In: Dilek, Y., et al. (Ed.), Ophiolites in Earth History. Special Publication, vol. 218. Geological Society, London, pp. 147-164.

Allegrè, C.J., et al., 1984. Structure and evolution of the Himalaya-Tibet orogenic belt. Nature 307, 17-22.

Anderson, J.L., 1996. Status of thermobarometry in granitic batholiths. Trans. Roy. Soc. Edinburgh Earth Sci. 87, 125-138.

Belousova, E.A., Griffin, W.L., O'Reilly, S.Y. Fisher, M.I., 2002. Igneous zircon: trace element composition as an indicator of source rock type. Contrib. Mineral. Petrol. $143,602-622$.

Black, L.P., et al., 2004. Improved ${ }^{206} \mathrm{~Pb} /{ }^{238} \mathrm{U}$ microprobe geochronology by monitoring of a trace-element-related matrix effect; SHRIMP, ID-TIMS, ELA-ICP-MS and oxygen isotope documentation for a series of zircon standards. Chem. Geol. 205, 115-140.

Booker, J.R., Favetto, A., Pomposlello, M.C., 2004. Low electrical resistivity associated with plunging of the Nazca flat slab beneath Argentina. Nature 429, 399-403. 
Booth, A.L., Zeitler, P.K., Kidd, W.S.F., 2004. U-Pb zircon constraints on the tectonic evolution of southeastern Tibet, Namche Barwa area. Am. J. Sci. 304, 889-929.

Burg, J.-P., Nievergelt, P., Oberli, F., et al., 1998. The Nambshe-Barwa syntaxis: evidence for exhumation related to compressional crustal folding. J. Asian Earth Sci. 16, 239-252.

Butler, R., 1995. When did India hit Asia? Nature 373, 20-21.

Chang, C.-F., Zheng, S.-L., 1973. Tectonic features of the Mount Jolmo Lungma region in southern Tibet, China. Sci. Geol. Sin. 1, 1-12.

Chappell, B.W., White, A.J.R., 1974. Two contrasting granite types. Pac. Geol. 8, $173-174$.

Chemenda, A.I., Burg, J.-P., Mattauer, M., 2000. Evolutionary model of the HimalayaTibet system: geopoem based on new modeling, geological and geophysical data. Earth Planet. Sci. Lett. 174, 397-409.

Chu, M.-F., 2006. Application of ICP-MS to the study of Transhimalayan petrogenesis. Unpubl. PhD thesis, National Taiwan University.

Chu, M.-F., Chung, S.-L., Song, B., et al., 2006. Zircon U-Pb and Hf isotope constraints on the Mesozoic tectonics and crustal evolution of southern Tibet. Geology 34, 745-748.

Chung, S.-L., Liu, D., Ji, J., et al., 2003. Adakites from continental collision zones: melting of thickened lower crust beneath southern Tibet. Geology 31, 1021-1024.

Chung, S.-L., Chu, M.-F., Zhang, Y., et al., 2005. Tibetan tectonic evolution inferred from spatial and temporal variations in post-collisional magmatism. Earth-Sci. Rev. 68, 173-196.

Collins, W.J., 2002. Hot orogens, tectonic switching, and creation of continental crust. Geology 30, 535-538.

Copeland, P., Harrison, T.M., Pan, Y., et al., 1995. Thermal evolution of the Gangdese Batholith, southern Tibet; a history of episodic unroofing. Tectonics 14, 223-236.

Coulon, C., Maluski, H., Bollinger, C., Wang, S., 1986. Mesozoic and Cenozoic volcanic rocks from central and southern Tibet: ${ }^{40} \mathrm{Ar} /{ }^{39} \mathrm{Ar}$ dating, petrological characteristics and geodynamic implications. Earth Planet. Sci. Lett. 79, 281-302.

Davies, J.H., von Blanckenburg, F., 1995. Slab breakoff: a model of lithosphere detachment and its test in the magmatism and deformation of collisional orogens. Earth Planet. Sci. Lett. 129, 85-102.

Debon, F., Le Fort, P., Sheppard, S.M.F., Sonet, J., 1986. The four plutonic belts of the Transhimalaya-Himalaya: a chemical, mineralogical, isotopic and chronological synthesis along a Tibet-Nepal section. J. Petrol. 27, 219-250.

Ding, L., Lai, C., 2003. Geologic evidence for preexisting crustal thickening and uplift in the Lhasa terrane before the Indo-Asian collision. Sci. China 48, 836-842.

Ding, L., Zhong, D., Yin, A., et al., 2001. Cenozoic structural and metamorphic evolution of the eastern Himalayan syntaxis (Namche Barwa). Earth Planet. Sci. Lett. 192, 423-438.

Ding, L., Kapp, P., Zhong, D., Deng, W., 2003. Cenozoic volcanism in Tibet: evidence from a transition from oceanic to continental subduction. J. Petrol. 44, 1833-1865.

Ding, L., Kapp, P., Wan, X., 2005. Paleocene-Eocene record of ophiolite obduction and initial India-Asia collision, south-central Tibet. Tectonics 24, TC3001. doi:10.1029/ 2004 TC001729.

Dubois-Cote, V., Hebert, R., Dupuis, C., et al., 2005. Petrologic and geochemical evidence for the origin of the Yarlung Zhanbo ophiolites, southern Tibet. Chem. Geol. 214 265-286.

Ducea, M.N., 2001. The California arc: thick granitic batholiths, eclogitic residues, lithosphere-scale thrusting, and magmatic flare-ups. GSA Today 11, 4-10.

Dupuis, C., et al., 2005. Petrology and geochemistry of mafic rocks from mélange and flysch units adjacent to the Yarlung Zangbo suture zone, southern Tibet. Chem. Geol. 214, 287-308.

England, P.C., Searle, M.P., 1986. The Cretaceous-Tertiary deformation of the Lhasa block and its implications for crustal thickening in Tibet. Tectonics 5, 1-14.

Geng, Q., Pan, G., Zheng, L., et al., 2006. The Eastern Himalayan syntaxis: major tectonic domains, ophiolitic mélanges and geologic evolution. J. Asian Earth Sci. 27, 265-285.

Gütscher, M.-A., Spakman, W., Bijwaard, H., Engdahl, E.R., 2000. Geodynamics of flat subduction: seismicity and tomographic constraints from the Andean margin. Tectonics 19, 814-833.

Harris, N.B.W., Xu, R.H., Lewis, C.L., et al., 1988. Isotope geochemistry of the 1985 Tibet transverse: Lhasa to Golmud. Philos. Trans. R. Soc. Lond. A327, 263-285

Harris, N.B.W., Inger, S., Xu, R.H., 1990. Cretaceous plutonism in central Tibet: an example of post-collision magmatism? J. Volcanol. Geotherm. Res. 44, 21-32.

Harrison, T.M., Yin, A., Grove, M., et al., 2000. The Zedong Window: a record of superposed Tertiary convergence in southeastern Tibet. J. Geophys. Res. 105, 19221-19230.

He, S., Kapp, P., DeCelles, P.G., et al., 2007. Cretaceous-Tertiary geology of the Gangdese Arc in the Linzhou area, southern Tibet. Tectonophysics 433, 15-37.

Heim, A., Gansser, A., 1939. Central Himalaya Geological Observations of Swiss Expeditions. Gebruder Fretz, Zurich, pp. 1-246.

Hodges, K.V., 2000. Tectonics of the Himalaya and southern Tibet from two perspectives. Geol. Soc. Amer. Bull. 112, 324-350.

Hoskin, P.W.O., Schaltegger, U., 2003. In: Manchar, J.M., Hoskin, P.W.O. (Eds.), The Composition of Zircon and Igneous and Metamorphic Petrogenesis. Zircon, Reviews of Mineralogy and Geochemistry, vol. 53, pp. 27-62.

Hu, D., Wu, Z., Ye, P., Jiang, W., 2003. SHRIMP U-Pb ages of zircons from dioritic gneiss in the Nyainqentanglha mountain, Tibet. Geol. Bull. China 22, 936-940 (in Chinese).

Hyndman, R.D., Currie, C.A., Mazzotti, S.P., 2005. Subduction zone backarcs, mobile belts, and orogenic heat. GSA Today 15 (no. 2), 4-10. doi:10:1130/1052-5173.

Ireland, T.R., Williams, I.S., 2003. In: Manchar, J.M., Hoskin, P.W.O. (Eds.), Considerations in Zircon Geochronology by SIMS. Zircon, Reviews of Mineralogy and Geochemistry, vol. 53, pp. 215-241.

Jiang, W., Mo, X.X., Zhao, C., et al., 1999. Geochemistry of granitoids and mafic microgranular enclaves in the Gangdese belt. Acta Petrol. Sin. 15, 89-97 (in Chinese).
Jin, C.W., Xu, R.H., 1984. Les granitoïdes de la partie centrale de l'Himalaya et du Gangdise au Xizang (Tibet) méridional. In: Mercier, J.L., Li, G.C. (Eds.), Mission Franco-Chinoise au Tibet 1980. Cent. Natl. Rech. Sci., Paris, pp. 289-308.

Kapp, J.L.D., Harrison, T.M., Kapp, P., et al., 2005a. Nyainqentanglha Shan: a window into the tectonic, thermal, and geochemical evolution of the Lhasa block, southern Tibet J. Geophys. Res. 110, B08413. doi:10.1029/2004JB003330.

Kapp, P., Yin, A., Harrison, T.M., Ding, L., 2005b. Cretaceous-Tertiary shortening, basin development, and volcanism in central Tibet. Geol. Soc. Amer. Bull. 117, 865-878.

Kapp, P., DeCelles, P.G., Gehrels, G.E., Heizler, M., Ding, L., 2007a. Geologic records of the Cretaceous Lhasa-Qiangtang and Indo-Asian collisions in the Nima basin area, central Tibet. Geol. Soc. Amer. Bull. 119, 917-932.

Kapp, P., DeCelles, P.G., Leier, A.L., et al., 2007b. The Gangdese retroarc thrust belt revealed. GSA Today $17,4-9$.

Kay, S.M., Mpodozis, K., 2001. Central Andean ore deposit linked to evolving shallow subduction systems and thickening crust. GSA Today 11 (no. 3), 4-9.

Kohn, M.J., Parkinson, C.D., 2002. Petrologic case for Eocene slab breakoff during the Indo-Asian collision. Geology 30, 591-594.

Lee, H.-Y., 2007. The Linzizong Volcanic Successions, southern Tibet: Ages, geochemical characteristics and petrogenesis. Unpubl. PhD thesis, National Taiwan University.

Lee, T.-Y., Lawver, L.A., 1995. Cenozoic plate reconstruction of Southeast Asia. Tectonophysics 251, 85-138.

Lee, H.-Y., Chung, S.-L., Wang, Y., et al., 2007. Zircon U-Pb and Hf isotopic constraints from the Linzhou basin on the onset timing and petrogenesis of the Linzizong Volcanic Successions, southern Tibet. Acta Petrol. Sin. 23, 493-500.

Leier, A.L., DeCelles, P.G., Kapp, P., Ding, L., 2007. The Takena Formation of the Lhasa terrane, southern Tibet: the record of a Late Cretaceous retroarc foreland basin. Geol. Soc. Amer. Bull. 119, 31-48.

Liang, Y.-H., Chung, S.-L., Liu, D., et al., 2004. Detrital zircon study along the Tsangpo River, SE Tibet. Eos Trans. AGU 85 (47) (Fall Meeting Abstract T53A-0466).

Liang, Y.-H., Chung, S.-L., Liu, D.-Y. et al., in press. Detrital zircon evidence from Burma for reorganization of the eastern Himalayan river system. Am. Jour. Sci.

Liu, D.-Y., Jian, P., Kröner, A., Xu, S.-T., 2006. Dating of prograde metamorphic events deciphered from episodic zircon growth in rocks of the Dabie-Sulu UHP complex, China. Earth Planet. Sci. Lett. 250, 650-666.

Maluski, H., Proust, F., Xiao, X.C., $1982 .{ }^{39} \mathrm{Ar} /{ }^{40} \mathrm{Ar}$ dating of the trans-Himalayan calcalkaline magmatism of southern Tibet. Nature 298, 152-154.

Maruyama, S., 1997. Pacific-type orogeny revisited: Miyashiro-type orogeny proposed. Isl. Arc 6, 121-142.

McDermid, I.R.C., Aitchison, J.C., Davis, A.M., et al., 2002. The Zedong terrane: a Late Jurassic intra-ocenaic magmatic arc within the Yarlung-Tsangpo suture zone, southeastern Tibet. Chem. Geol. 187, 267-277.

Miller, C., Schuster, R., Klötzli, U., et al., 1999. Post-collisional potassic and ultrapotassic magmatism in SW Tibet: geochemical and $\mathrm{Sr}-\mathrm{Nd}-\mathrm{Pb}-\mathrm{O}$ isotopic constraints for mantle source characteristics and petrogenesis. J. Petrol. 40,1399-1424.

Mo, X.X., Dong, G., Zhao, Z., et al., 2005. Spatial and temporal distribution and characteristics of granitoids in the Gangdese, Tibet and implication for crustal growth and evolution. Geol. J. Chinese University 11, 281-290.

Murphy, M.A., Yin, A., Harrison, T.M., et al., 1997. Did the Indo-Asian collision alone create the Tibetan plateau? Geology 25, 719-722.

Pan, G., Ding, J., Yao, D., Wang, L., compilers, 2004. The Guide Book of 1: 1,500,000 geologic map of the Qinghai-Xizang (Tibet) plateau and adjacent areas. Chengdu Cartographic Publication House, 48 p.

Pitcher, W.S., 1982. Granite type and tectonic environment. In: Hsü, K.J. (Ed.), Mountain Building Processes. Academic Press, London, pp. 19-40.

Quidellieur, X., Grove, M., Lovera, T.O.M., et al., 1997. The thermal evolution and slip history of the Renbu-Zedong Thrust, southeastern Tibet. J. Geophys. Res. 102, 2659-2679.

Ratschbacher, L., Frisch, W., Chen, C., Pan, G., 1993. Deformation and motion along the southern margin of the Lhasa block (Tibet) prior to and during the India-Asia collision. J. Geodyn. 16, 21-54.

Saleeby, S., 2003. Segmentation of the Laramide Slab - evidence from the southern Sierra Nevada region. Geol. Soc. Amer. Bull. 115, 655-668.

Schärer, U., Xu, R.H., Allègre, C.J., 1984. U-Pb geochronology of Gangdese (Transhimalaya) plutonism in the Lhasa-Xigaze region, Tibet. Earth Planet. Sci. Lett. 69, $311-320$.

Schmidt, M.W., Poli, S., 2004. In: Schmidt, M.N., Poli, S. (Eds.), Magmatic Epidote. Rev. Mineral. Geochem., vol. 56, pp. 399-430.

Searle, M.P., Windley, B.F., Coward, M.P., et al., 1987. The closing of Tethys and the tectonics of the Himalaya. Geol. Soc. Amer. Bull. 98, 678-701.

van de Zedde, D.M.A., Wortel, M.J.R., 2001. Shallow slab detachment as a transient source of heat at midlithospheric depths. Tectonics 20, 868-882.

Wen, D.-J., 2007. The Gangdese Batholith, southern Tibet: ages, geochemical characteristics and petrogenesis. Unpubl. PhD thesis, National Taiwan University.

Wen, D.-J., Chung, S.-L., Liu, D., et al., 2003. New SHRIMP U-Pb zircon ages from the Gangdese batholith and implications for the Trans-Himalayan magmatic evolution. Geophys. Res. Abstr. 5, 494.

Wen, D.-J., Chung, S.-L., Song, B. et al., in press. Late Cretaceous Gangdese intrusions of adakitic geochemical characteristics, SE Tibet: petrogenesis and tectonic implications. Lithos.

XBGMR (Xizang Bureau of Geology and Mineral Resources), 1993. Regional Geology of Xizang (Tibet) Autonomous Region. Geologic Publication House, China. 707 pp. (in Chinese with English abstract).

Xu, R.H., Schärer, U., Allegrè, C.J., 1985. Magmatism and metamorphism in the Lhasa block (Tibet): a geochronological study. J. Geol. 93, 41-57.

Yin, A., Harrison, T.M., 2000. Geologic evolution of the Himalayan-Tibetan orogen. Annu. Rev. Earth Planet. Sci. 28, 211-280. 
Yin, J., Grant-Mackie, J.A., 2005. Late Triassic-Jurassic bivalves from volcanic sediments of the Lhasa block, Tibet. N.Z. J. Geol. Geophys. 48, 555-576.

Yin, J., Xu, J., Lin, C., Huan, L., 1988. The Tibetan Plateau: regional stratigraphic context and previous work. Philos. Trans. R. Soc. Lond., Ser. A 327, 5-52.

Yin, A., Harrison, T.M., Ryerson, F.J., et al., 1994. Tertiary structural evolution of the Gangdese thrust system, southeastern Tibet. J. Geophys. Res. 99, 18175-18201.

Yin, A., Harrison, T.M., Murphy, M.A., et al., 1999. Tertiary deformation history of southeastern and southwestern Tibet during the Indo-Asian collision. Geol. Soc. Amer. Bull. 111, 1644-1664.
Zen, E.-a., 1985. Implications of magmatic epidote-bearing plutons on crustal evolution in the accreted terranes of northwestern North America. Geology 13, 266-269.

Zhang, K.J., Xia, B.D., Wang, G.M., et al., 2004. Early Cretaceous stratigraphy, depositional environment, sandstone provenance, and tectonic setting of central Tibet, western China. Geol. Soc. Amer. Bull. 116, 1202-1222.

Zhu, D.-C., Pan, G., Chung, S.-L., et al., 2008. SHRIMP zircon age and geochemical constraints on the origin of lower Jurassic volcanic rocks from the Yeba Formation, southern Gangdese, south Tibet. Int. Geol. Rev. 50, 422-471. 